\title{
Analysis of Selected Profitability Ratios in the Agricultural Sector
}

Renata Aulová, Ludmila Pánková, Lenka Rumánková

Faculty of Economics and Management, Czech University of Life Sciences Prague, Czech Republic

\begin{abstract}
The paper deals with the analysis of selected profitability indicators of Czech agricultural businesses of legal entities and their subcomponents, based on DuPont analysis. The effect of asset turnover ratio, net profit margin ratio and equity multiplier on the value of return on equity (ROE) and return on assets (ROA) is studied in relation to the legal form and size group. The analysis of the effect of sub-indicators is performed by way of a correlation analysis. Furthermore, the assumption about the influence of sub-components indicators on synthetic profitability ratios is verified.

The panel data set we used was obtained from the Amadeus database. The analytical section is based upon accounting statements of agricultural businesses of legal entities in the Czech Republic within the period of $2011-2015$. The analysis is based on the calculated values of ROA and ROE, including partial values of the sub-components indicator, by using DuPont analysis. The differences between the groups of businesses are tested through correlation analysis and subsequently evaluated with respect to the specifics of each group. The object of examination was more than 3000 companies annually, on average. The evaluated companies were divided, in terms of legal form, into joint-stock companies, cooperatives and limited liability companies, and in terms of size structure into small, medium and large businesses.
\end{abstract}

\section{Keywords}

Return on assets, return on equity, DuPont analysis, agricultural enterprise, company size, legal form, correlation analysis.

Aulová, R., Pánková, L. and Rumánková, L. (2019) "Analysis of Selected Profitability Ratios in the Agricultural Sector", AGRIS on-line Papers in Economics and Informatics, Vol. 11, No. 3, pp. 3-12. ISSN 1804-1930. DOI 10.7160/aol.2019.110301.

\section{Introduction}

The evaluation of the efficiency and profitability of a business, regardless of its field of activity, comprises a significant part of managerial decisionmaking in terms of operational and strategic management. On the basis of such an evaluation, one can judge as to the overall performance of a business, of which the definition and methods of measurement have been an object of interest of many expert studies and authors (Král, Wagner and Stránský, 2006; Kaplan and Norton, 2007; Sardana, 2008; Antony and Bhattacharyya, 2010; Wagner, 2011; Schader et al., 2016; Vastola et al., 2017; Ssebunya et al., 2019) for several years now.

The performance of a business is an important gauge not only for the management of the business itself, but also for external entities that come into contact with the business, and this is precisely why it can be interpreted and comprehended in various ways. However, in recent years, there has been a noticeable trend in the measurement of performance toward the use of indicators that prefer the market value of a business and take into consideration criteria of economic and environmental sustainability, as opposed to traditional indicators whose foundations are based upon accounting. Nevertheless, in practice, emphasis is still placed specifically upon measuring the financial performance of businesses, a very important gauge for both internal and external users. In this regard, rate of return indicators in particular are thus of vital significance, as the overall efficiency of a business can be evaluated on the basis of them, and the causes of trends in the achieved economic results can also be revealed through their analysis.

An analysis of profitability can be based, for example, upon a detailed examination of rate of return indicators by using DuPont analysis and evaluating the impact of factors that influence the given synthetic indicator. Such an approach, which is also the basis for this article, can be seen in the publications of authors within a worldwide context. As shown in publications by, for example, 
(Bumbescu, 2015; Soliman, 2003, 2008; Liesz, 2004; Mishra et al., 2012; Sheela and Karthikeyan, 2012; Burja and Mărginean, 2014; Chang, Chichernea and HassabElnaby, 2014; Doorasamy, 2016; Reiff et al., 2016), analysis of rate of return indicators using DuPont analysis is truly a globally recognized methodological approach. However, such a concept is also used by Czech authors. Its significance and utilization in the area of agricultural and foodprocessing businesses is apparent, for example, in the following publications: Machek and Špička, (2014), Vítková and Semenova (2015), Novotná and Svoboda (2010), Střeleček and Zdeněk (2018), and Kocisova et al. (2018).

An analysis of synthetic rate of return indicators can be successfully based upon a DuPont analysis. However, the key task within the entire analysis should be to ascertain the influence of sub-indicators upon the synthetic indicator. Identifying the main factors influencing the ROE, ROA or ROS indicators and explaining their influence upon profitability and the formation of the value of a business can be done, for example, by utilizing correlation analysis and regression analysis. The impact of selected factors upon the economic results of businesses operating within the Czech agri-food market is addressed, for example, in the following publications: Náglová and Horáková (2016), Aulová, Rumánková and Ulman (2013), Lososová and Zdeněk (2014), Novotná and Svoboda (2010), Novotná and Volek (2015), and Brožová and Beranová (2017).

\section{Materials and methods}

The objective of this article is to verify the assumption that there exist significant differences in the impact of ratio sub-indicators upon the synthetic indicator of return on assets (ROA) and return on equity (ROE) among individual groups of agricultural businesses of legal entities in the Czech Republic, in terms of both legal form and their size. The main objective is fulfilled by way of the following sub-objectives:

- definition of synthetic indicators for the DuPont analysis;

- $\quad$ specification of analytical sub-determinants of return on assets and return on equity on the basis of the DuPont analysis;

- evaluation of the strength of correlation of the synthetic indicator in regard to analytical indicators, within both individual size groups and legal forms of agricultural businesses, within the years being assessed.
The analytical section is based upon longitudinal data obtained from the Amadeus database. Specifically, financial statements of agricultural businesses of legal entities in the Czech Republic for the period of 2011-2015 have been used. Agricultural businesses of legal entities are divided according to legal form into joint stock companies (JSC), cooperatives (COOP) and limited liability companies (LLC) with their predominant activity being agriculture, namely category 01 according to the CZ-NACE classification. The authors consider non-included activities from category $01 \mathrm{CZ}-\mathrm{NACE}$ to be irrelevant, in view of the object of evaluation and its proportion in the income of agricultural businesses.

Size groups of businesses are defined on the basis of the AMADEUS database methodology as large (L), medium (M) and small (S) businesses.

Large Companies:

- $\quad$ Operating revenue $\geq 10$ million EUR

- Total assets $\geq 20$ million EUR

- $\quad$ Employees $\geq 1000$

Medium - sized Companies:

- $\quad$ Operating revenue $\geq 1$ million EUR

- $\quad$ Total assets $\geq 2$ million EUR

- $\quad$ Employees $\geq 15$

Small Companies

- all companies not included into the above categories

The structure of analyzed companies and its difference between years 2011 and 2015 can be seen in Table 1.

Decrease of the number of the enterprises in analyzed period is obvious; from viewpoint of the type of the company as well as its size. It can be stated that the number of LLC exceeds the number of JSC and COOPs. Also, the smallest share of large companies among all analyzed companies is obvious. However, the structure of each type of the company can be considered as stable in the analyzed period.

The variability of ROA and ROE is closely related to the negative value of these indicators. Negative values of ROE were detected especially in group of small cooperatives while negative values of ROA are characteristic for groups of all small enterprises. The negative value of ROA is connected to the loss while the negative value of ROE is based not only on the loss but also on the negative value of equity; that is common for small companies and is usually 


\begin{tabular}{|l|r|r|r|r|r|r|}
\hline Company & \multicolumn{2}{|c|}{ JSC } & \multicolumn{2}{c|}{ LLC } & \multicolumn{2}{c|}{ COOP } \\
\hline Period & $\mathbf{2 0 1 1}$ & $\mathbf{2 0 1 5}$ & $\mathbf{2 0 1 1}$ & $\mathbf{2 0 1 5}$ & $\mathbf{2 0 1 1}$ & $\mathbf{2 0 1 5}$ \\
\hline Small & 105 & 75 & 1468 & 1359 & 120 & 79 \\
\hline Medium & 462 & 374 & 747 & 578 & 389 & 330 \\
\hline Large & 87 & 79 & 18 & 15 & 41 & 40 \\
\hline
\end{tabular}

Source: own processing

Table 1: Number of companies.

produced by cumulative losses of the previous periods.

In order to define the relations between synthetic indicators (ROA, ROE) and analytical indicators, the DuPont model has been used. The model is based upon the basic indicator of return on assets, which is given as the result of the multiplier effect of the profit margin and sales turnover, with a subsequent modification, or extended in view of the impact of financial leverage (Sheela and Karthikeyan, 2012). A basic diagram of this analysis can be shown to have the following structure:

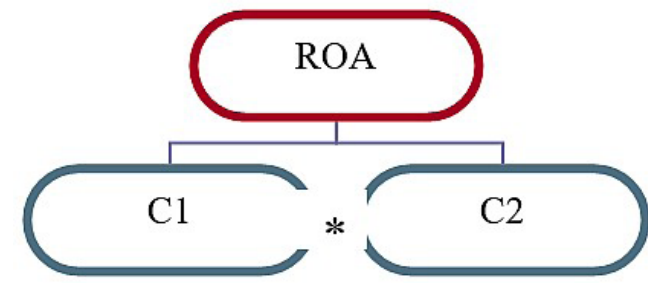

Source: own processing, according Sheela and Karthikeyan (2012)

Figure 1: Return on assets.

ROA $=$ Net Profit $/$ Assets

$\mathrm{C} 1=$ Return on Sales $=$ Net Profit $/$ Sales

$\mathrm{C} 2=$ Assets Turnover $=$ Sales $/$ Total Assets

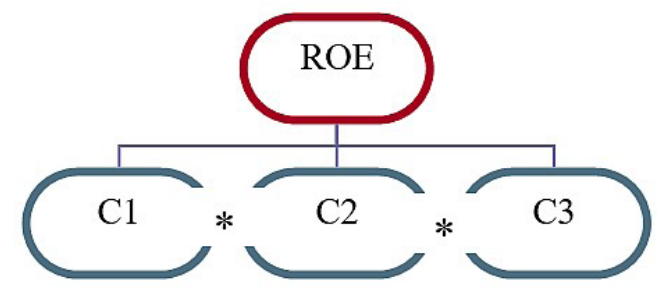

Source: own processing, according Sheela and Karthikeyan (2012)

Figure 2: Return on equity.

ROE $=$ Net Profit /Equity

$\mathrm{C} 1=$ Return on Sales $=$ Net Profit $/$ Sales

$\mathrm{C} 2=$ Assets Turnover $=$ Sales $/$ Total Assets

C3 $=$ Financial Leverage $=$ Total Assets/Equity

The relationship between individual sub-indicators and the aggregate indicator (ROE, ROA) has been examined by way of correlation analysis, specifically by utilizing the Pearson correlation coefficient. The correlation coefficient ( $r$ ) can be calculated on the basis of the following relationship ${ }^{1}$ :

$$
r=\frac{\sum_{i=1}^{n}\left(x_{i}-\bar{x}\right)\left(y_{i}-\bar{y}\right)}{\sqrt{\sum_{i=1}^{n}\left(x_{i}-\bar{x}\right)^{2} \sum_{i=1}^{n}\left(y_{i}-\bar{y}\right)^{2}}},
$$

where $\mathrm{x}$ and $\mathrm{y}$ are random variables with a common normal distribution. The values of the correlation coefficient are within the interval of $<-1 ; 1>$. Results of correlation coefficients nearing the value of $|1|$ show the aggregate indicator to have a strong correlation to the given sub-indicator. Positive values show a positive correlation, while negative values show a negative relationship between the indicators being examined. A value of the correlation coefficient equal to 0 says that the variables being examined are not correlated.

In individual years, correlation coefficients were calculated for individual sub-determinants of the synthetic indicators ROA and ROE. The decisive sub-determinants in terms of the strength of the correlation of the synthetic indicator were thus always selected so as to be those that showed the highest value of the correlation coefficient. Moreover, the significance of the correlation coefficients was verified using t-test. In conclusion, given coefficients were mostly statistically significant on the significance level $\alpha=0.05$ or $\alpha=0.10$, respectively. In terms of the classification of businesses, this was conducted according to both legal form and size group.

1 The DuPont analysis in combination with correlation analysis is used, for example, by Bumbescu (2015) and Focsan et al. (2015) 


\section{Results and discussion}

\section{Results of the analysis of return on assets}

On the basis of the conducted correlation analysis, it is possible to state that significant differences exist in the impact of individual analytical sub-indicators on the synthetic indicator ROA, in terms of both legal form and size of the business (Table 2).

\section{Small Businesses - ROA}

Profit margin (or return on sales) and, to a lesser degree and only in some years, assets turnover, can be considered significant determinants impacting the value of the ROA for SMALL businesses of various legal forms. Whereas for small joint stock companies and cooperatives there is a predominating correlation proximity between ROA and return on sales within the five-year period under consideration, for limited liability companies the main determinant was seen to be assets turnover. All of the analyzed correlation proximities can, in the case of small businesses, be considered direct linear correlations for the determinant of return on sales. On the other hand, the correlation proximity between return on total capital and assets turnover was evaluated as negative. This means that while growth in return on sales leads to growth in return on total capital, growth in the speed of assets turnover leads to a decline in the main indicator being analyzed (ROA).

In the case of small joint stock companies, a moderate rate of direct linear correlation between ROA and return on sales was proven on the basis of the Pearson correlation coefficient. The proven correlation can be considered statistically significant at a significance level of $\alpha=0,05$. The effect of the second of the sub-determinants, i.e. assets turnover, can be considered statistically significant within only one year (2014), where an indirect linear correlation between the indicators being assessed was proven. This means that growth in assets turnover led to a decrease in the value of ROA. In the case of small limited liability companies, a low to moderate strength of correlation proximity between ROA and assets turnover was proven.
Within the entire period being assessed, this was an indirect correlation, and therefore growth in the value of assets turnover brought about a decrease in the return on total assets. In the case of small cooperatives, the relationship between return on sales and ROA was shown to be more significant; the rate of correlation proximity reached a correlation coefficient value of up to 0.3 , and the direction of the effect of return on sales on ROA is a positive one. In one of the assessed periods (the year 2011), assets turnover had a negative effect on ROA, with a mild to moderate degree of correlation.

\section{Medium Businesses - ROA}

For MEDIUM-sized businesses, the conducted analysis of relation between return on total capital and its main determinants indicates a predominating correlation proximity between return on total assets and return on sales. This is a direct linear correlation that is reflected in instances of a growing profit margin through a growing return on total capital. The effect of such growth can, in isolated cases, be offset by a negative correlation proximity between ROA and assets turnover (as occurs, for example, in the case of medium joint stock companies in 2011 or medium limited liability companies in 2014). On the other hand, in the case of medium cooperatives, one can find a positive rate of correlation proximity between assets turnover and return on total capital.

In the case of medium-sized joint stock companies, significant differing values of correlation coefficients were identified in the course of the period being assessed. Whereas in the years 2011, 2014 and 2015, the strength of correlation proximity between ROA and return on sales was low, in the years 2012 and 2013 it can be assessed as medium. Within the entire period being assessed, such correlation can be considered positive, i.e., direct (growth of one variable will lead to the growth of the other variable and vice versa). In the years 2011 and 2012, assets turnover can be considered a statistically significant sub-determinant, with a moderate to medium

\begin{tabular}{|c|c|c|c|c|}
\hline ROA & Small & Medium & Large & Intervals of correlation coefficient \\
\hline JSC & $\mathrm{C} 1 *$ & $\mathrm{C} 1$ & $\mathrm{C} 1 *$ & $0-0.39$ \\
\hline LLC & $\mathrm{C} 2$ & $\mathrm{C} 1$ & $\mathrm{C} 1$ & $0.4-0.69$ \\
\hline COOP & $\mathrm{C} 1$ & $\mathrm{C} 1$ & $\mathrm{C} 1$ & $0.7-1.0$ \\
\hline
\end{tabular}

Note: *cannot be unequivocally determined (i.e., there are not at least 3 equal values) Source: own processing

Table 2: Results of Return on Assets. 
strength of correlation proximity. However, the achieved results do not unequivocally confirm a direct correlation between the variables being assessed. In the case of medium limited liability companies, it cannot be clearly proven that assets turnover has as indirect effect on the value of ROA. Within three of the five years being assessed, the correlation proximity between ROA and return on sales was assessed as being low, with a direct correlation.

In the case of medium-sized cooperatives, a positive effect of return on sales predominates within the three years being assessed $(2011,2012,2013)$, which is before assets turnover at the conclusion of the period being assessed (the years 2014 and 2015), while the rate of correlation proximity greatly differs (on the timeline, it is seen to be mild, medium to high for return on sales, and low to medium for assets turnover).

\section{Large Businesses - ROA}

Unequivocal conclusions arose from the analysis of sub-determinants of ROA in the case of large companies of all legal forms. According to the results, it is typical for large businesses that return on equity is determined, on a long-term basis, by return on sales, which is classified as having a medium-to-high rate of correlation proximity.

For large joint stock companies, it can be unequivocally stated that the analytical sub-indicator of return on sales shows a strong rate of correlation proximity in relation to ROA, with the exception of one of the assessed periods. A very high degree of correlation was also found between ROA and return on sales within all of the assessed periods for large limited liability companies. This was a direct correlation. On the timeline of the period being assessed, large cooperatives show identical results, which indicates a very high rate of correlation proximity between return on sales and return on total capital.

\section{Results of the analysis of return on equity}

The results of the analysis of return on equity are summarized in Table 3.

\section{Small Businesses - ROE}

The results of an assessment of the relationship between return on equity and its sub-determinants within the agriculture, forestry and fishing sectors indicate the significance of financial leverage, primarily in the case of SMALL companies having the legal form of joint stock company and limited liability company. The effect of financial leverage impacts negatively upon return on equity. In the case of small joint stock companies, the indicator of financial leverage with a mediumto-high rate of correlation proximity was defined when analyzing the decisive determinants affecting the size of ROE. Statistically, an indirect effect of such a variable on the synthetic indicator was confirmed. For small limited liability companies, financial leverage was also unequivocally determined as the dominant analytical indicator, with an indirect effect on the evolution of ROE. The rate of correlation proximity was evaluated within the years being assessed as low. In the case of small cooperatives, unequivocal conclusions cannot be determined in terms of the effect of sub-determinants on the synthetic indicator. Within the period being assessed, a significant dissimilarity is apparent in terms of the direction and rate of correlation proximity between the indicators being analyzed. A medium and high rate of correlation proximity between financial leverage and ROE was identified in the years 2011 and 2014, but in the years 2012 and 2015 the correlation between return on sales and ROE is shown to be of medium strength. However, in all cases, the effect of sub-determinants on the indicator as a whole has an alternating positive and negative direction. In one of the periods being assessed, the indicator of assets turnover also appeared to be the most significant, but with a moderate positive degree of correlation between the variables being analyzed.

\section{Medium Businesses - ROE}

Just as in the case of small joint stock companies and limited liability companies, MEDIUM joint stock companies and limited liability companies

\begin{tabular}{|c|c|c|c|c|}
\hline ROA & Small & Medium & Large & Intervals of correlation coefficient \\
\hline JSC & $\mathrm{C} 3$ & $\mathrm{C} 3$ & $\mathrm{C} 3$ & $0-0.39$ \\
\hline LLC & $\mathrm{C} 3$ & $\mathrm{C} 3$ & $\mathrm{C} 1$ & $0.4-0.69$ \\
\hline COOP & $\mathrm{C} 3$ & $\mathrm{C} 3$ & $\mathrm{C} 1$ & $0.7-1.0$ \\
\hline
\end{tabular}

Source: own processing 
also show a provable rate of correlation proximity between ROE and financial leverage. For medium joint stock companies, the indicator of financial leverage was also identified as a statistically significant determinant affecting the value of ROE. However, for medium joint stock companies, an indirect effect on the value of return on equity cannot be unequivocally proven, as is the case for the group of small joint stock companies. For medium joint stock companies, it can be unequivocally stated that the analytical sub-indicator of return on sales shows a strong rate of correlation proximity in relation to ROA, with the exception of one of the periods being assessed. A moderate rate of correlation proximity was also proven for return on sales and assets turnover, generally with a predominating positive effect on the synthetic indicator. Limited liability companies can be characterized as having a rather predominating indirect effect between financial leverage and ROE. In the case of medium cooperatives, the results of correlation analysis are significantly heterogeneous. Within two of the periods being assessed (2012, 2015), financial leverage has a predominating effect, while its effect in the year 2015 is negative, with a medium rate of correlation proximity between the variables. In the years 2013 and 2014, variable $\mathrm{C} 2$ shows a moderate degree of correlation proximity, i.e. assets turnover with a direct correlation. In 2011, a positive effect of return on sales with a low rate of correlation proximity predominates for medium cooperatives.

\section{Large Businesses - ROE}

In the case of LARGE businesses, differences were identified between individual legal forms. For large joint stock companies, one can find (similarly to small joint stock companies) a statistically significant medium-to-high rate of correlation proximity, with a negative impact for the financial leverage variable. Different results can be seen for large limited liability companies, where the decisive factor for the evolution of ROE was identified as being return on sales, with a high degree of correlation and a direct effect. A medium rate of correlation proximity can also be proven in regard to financial leverage, with a direct effect, which is the opposite result compared to the other size groups for limited liability companies. Large cooperatives within the period of 2011 to 2014 show a high rate of correlation proximity between return on sales and return on equity, with a positive direction of the effect.

The achieved results of the correlation analysis show a differing effect of the sub-determinants on the value of the synthetic indicator ROA for the individual size groups and legal forms within the years being assessed.

While a stronger impact of assets turnover on the value of ROA was proven in the case of small limited liability companies, in the case of small joint stock companies (as well as small cooperatives) return on sales was shown to be decisive. It is thus apparent that for small companies, the ability to effectively utilize invested assets has a large impact upon the achieved rate of return.

In the case of both medium and large businesses of all legal forms, it was clearly proven that return on sales has the strongest impact on the value of the indicator of ROA. For these companies, it can thus be presumed that profit margin is the decisive factor in a business's performance within a given year. The average realization price is thus a decisive factor for performance in the case of businesses that are stable in terms of assets. The profit margin enables an evaluation of the ability of businesses to achieve profit at a given level of sales, and reflects the price strategy of the company and its ability to manage operating costs. In terms of achieved results, these are thus in accordance with the results of Chang, Chichernea and HassabElnaby (2014), who specifically define profit margin as the most important indicator of the future evolution of rate of return. On the contrary, this result is not in accordance with the conclusions of Fairfield and Yohn (2001), who consider a more important factor in terms of the evolution of profitability to be the assets turnover rate. However, it is necessary to realize that the agriculture sector has its specifics, which can be reflected specifically in profitability results (e.g., seasonality, the biological nature of production, duality of the structure of agricultural businesses, and other factors).

For all legal forms of medium and small businesses, the influence of financial leverage on the value of the indicator ROE was proven. In the case of large businesses, financial leverage was decisive for the evolution of ROE in the case of joint stock companies. Current specialized studies indicate that small and medium businesses have more limited access to external financing resources and are thus more dependent upon generated internal resources/profit (Uyar and Guzelyurt, 2015; Anuar and Chin, 2016). Large businesses usually have lower bankruptcy costs and are more diversified, and that positively affects their access to third-party capital (Rajan and Zingales, 1995; 
Chen, 2004; Weill, 2004; Song, 2005; Delcoure, 2007). In the case of large limited liability companies and cooperatives, return on sales had a decisive influence on the value of ROE, which can be explained as cited above. They state in their study that the evolution of individual parameters of profitability indicators has a much greater significance for estimating the future evolution of a business's profitability than does their value. Soliman (2008) then confirms that changes in the assets turnover rate explain changes in the future evolution of the profitability being achieved by a business. At the same time, Soliman also states that changes in individual sub-determinants of rates of return provide useful information regarding the operating characteristics of companies and can influence both the market value of a company as well as the prognosis for the business on the part of analysts.

As considered Czech agricultural businesses, profitability indicators are analyzed mainly as time series development or relating selected performance indicators (Machek and Špička, 2014; Lososová and Zdeněk, 2014; Náglová and Horáková, 2016). Based on the Du Pont model, Mishra et al. (2012) identified the profitability key drivers in US farms. As key factors affecting profitability are defined specialization and receiving government payments.

\section{Conclusion}

The aim of the paper was to verify the assumption that there exist significant differences in the impact of ratio sub-indicators upon the synthetic indicator of return on assets (ROA) and return on equity (ROE) among individual groups of agricultural businesses of legal entities in the Czech Republic, in terms of both legal form and their size. The analysis was based on longitudinal data obtained from the Amadeus database, concretely financial statements of agricultural businesses of legal entities in the Czech Republic for the period 2011 - 2015. The relationship between individual sub-indicators and the aggregate indicator
(ROE, ROA) was examined by way of correlation analysis, specifically by utilizing the Pearson correlation coefficient. Moreover, the impact of individual sub-indicators was compared among different size-groups businesses (small, medium and large) as well as different legal-form businesses (JSC, LLC, COOP).

It is obvious, that the profitability indicators are influenced by several factors and the intensity of their influence differs. The development of the profitability can not be considered as identic for all analyzes size-groups businesses as well as the legal-form businesses. The values of ROA and ROE can be influenced by cost management or management of production expenses. Due to the position of agriculture in the national economy, with no power to state the market prices; the cost management can be considered as an appropriate way to control and manage the profitability.

The cost management may employ target inputs application connected to the application of fertilizers, seeds or chemical preservation. Also the diversification and specialization of business activities can be employed effectively. Thus, several ways are in compliance with CAP and target support of e.g. investments in the framework of precision agriculture, fixed assets modernization, or a diversification.

On the basis of the conducted analysis of indicators of rate of return, based upon the DuPont analysis, it is possible to state that significant differences do exist in the impact of individual ratio indicators on the synthetic indicator, in terms of both legal form and size of the business.

\section{Acknowledgements}

The results are the part of the solution of project No. QK1920398, supported by the Ministry of Agriculture of the Czech Republic, program ZEMĚ.

\author{
Corresponding authors \\ Ing. Renata Aulová, Ph.D. \\ Department of Economics, Faculty of Economics and Management \\ Czech University of Life Sciences Prague, Kamycka 129, Prague - Suchdol, 165 00, Czech Republic \\ Phone: +420224382 060, E-mail: aulova@pef.czu.cz
}




\section{References}

[1] Antony, J. P. and Bhattacharyya, S. (2010) "Measuring organizational performance and organizational excellence of SMEs - Part 1: A conceptual framework", Measuring Business Excellence, Vol. 14, No. 2, pp. 3-11. ISSN 1368-3047. DOI 10.1108/13683041011047812.

[2] Anuar, H. and Chin, O. (2016) "The Development of Debt to Equity Ratio in Capital Structure Model: A Case of Micro Franchising", Procedia Economics and Finance, Vol. 35, pp. 274-280. ISSN 2212-5671. DOI 10.1016/s2212-5671(16)00034-4.

[3] Aulová, R., Rumánková, L. and Ulman, M. (2013) "Determinants of the result of economic activity of agricultural businesses of legal entities in the Czech Republic", Acta Universitatis Agriculturae et Silviculturae Mendelianae Brunensis, Vol. 61, No. 4, pp. 849-859. E-ISSN 2464-8310, ISSN 1211-8516. DOI 10.11118/actaun201361040849.

[4] Brožová, I. and Beranová, M. (2017) "A comparative analysis of organic and conventional farming profitability", Agris On-line Papers in Economics and Informatics, Vol. 9, No. 1, pp. 3-15. ISSN 1804-1930. DOI 10.7160/aol.2017.090101.

[5] Bumbescu, S. S. (2015) "Performance analysis in agriculture using Du Pont model", Alma Mater University journal, Alma Mater University Jornal of Sibiu, Vol. 8, No. 2, pp. 41-47.

[6] Burja, V. and Mărginean, R. (2014) "The Study of Factors that may Influence the Performance by the Dupont Analysis in the Furniture Industry", Procedia Economics and Finance, Vol. 16, pp. 213-223. ISSN 2212-5671. DOI 10.1016/S2212-5671(14)00794-1.

[7] Chang, K. J., Chichernea, D. C. and HassabElnaby, H. R. (2014) "On the DuPont analysis in the health care industry", Journal of Accounting and Public Policy, Vol. 33, No. 1, pp. 83-103. ISSN 0278-4254. DOI 10.1016/j.jaccpubpol.2013.10.002.

[8] Chen, J. J. (2004) "Determinants of capital structure of Chinese-listed companies", Journal of Business Research, Vol. 57, No. 12, pp. 1341-1351. ISSN 0148-2963. DOI 10.1016/S0148-2963(03)00070-5.

[9] Delcoure, N. (2007) "The determinants of capital structure in transitional economies", International Review of Economics and Finance, Vol. 16, No. 3, pp. 400-415. ISSN 1059-0560. DOI 10.1016/j.iref.2005.03.005.

[10] Doorasamy, M. (2016) "Using DuPont analysis to assess the financial performance of the top 3 JSE listed companies in the food industry", Investment Management and Financial Innovations, Vol. 13, No. 2, pp. 29-44. E-ISSN 1812-9358, ISSN 1810-4967. DOI 10.21511/imfi.13(2).2016.04.

[11] Fairfield, P. M. and Yohn, T. L. (2001) "Using asset turnover and profit margin to forecast changes in profitability", Review of Accounting Studies, Vol. 6, No. 4, pp. 371-385. E-ISSN 1573-7136, ISSN 1380-6653. DOI 10.1023/A:1012430513430.

[12] Focsan, I. E., Miron, V. C. I. and Jeler (Popa), I. (2015) "Du Pont Analysis In The Production And Preservation Of Meat", Annals - Economy Series, Vol. 1, pp. 140-146.

[13] Kaplan, R. S. and Norton, D. P. (2007) "Using the balanced scorecard as a strategic management system", Harvard Business Review. [Online]. Available: https://hbr.org/2007/07/using-the-balancedscorecard-as-a-strategic-management-system [Accessed: 25 July 2019].

[14] Kocisova, K., Gavurova, B. and Kotaskova, A. (2018) "A slack-based measure of agricultural efficiency in the European Union countries, Journal of International Studies, Vol. 11, No. 1, pp. 189-200. E-ISSN 2306-3483, ISSN 2071-8330. DOI 10.14254/2071-8330.2018/11-1/14.

[15] Král, B., Wagner, J. and Stránský, J. (2006) "Vývojové tendence v systémech ř́zení výkonnosti" (In Czech), Český finanční a účetní časopis, Vol. 1, No. 3, pp. 33-42. ISSN 1802-2200. DOI 10.18267/j.cfuc.176.

[16] Liesz, T. J. (2004) "Really Modified DuPont Analysis: Five Ways to Improve Return on Equity", The Economics Review. [Online]. Available: http://citeseerx.ist.psu.edu/viewdoc/ download?doi=10.1.1.610.5026\&rep=rep1\&type=pdf [Accessed: 22 July 2019]. 
[17] Lososová, J. and Zdeněk, R. (2014) "Key factors affecting the profitability of farms in the Czech Republic", Agris On-line Papers in Economics and Informatics, Vol. 6, No. 1, pp. 1-16. ISSN 1804-1930.

[18] Machek, O. and Špička, J. (2014) "Productivity and profitability of the Czech agricultural sector after the economic crisis", WSEAS Transactions on Business and Economics. [Online]. Available: http://www.wseas.org/multimedia/journals/economics/2014/a265707-083.pdf [Accessed: 20 July 2019].

[19] Mishra, A. K., Harris, J. M., Erickson, K. W. Hallahan, Ch. and Detre, J. D. (2012) "Drivers of agricultural profitability in the USA: An application of the Du Pont expansion method", Agricultural Finance Review. Vol. 72 No. 3, pp. 325-340. ISSN 0002-1466. DOI 10.1108/00021461211277213.

[20] Náglová, Z. and Horáková, T. (2016) “Influence of Qualitative Factors on Quantitative Determinants in the Czech Meat Industry Economy", AGRIS on-line Papers in Economics and Informatics, Vol. 8, No. 4, pp. 111-123. ISSN 1804-1930. DOI 10.7160/aol.2016.080410.

[21] Novotná, M. and Svoboda, J. (2010) "Application of a system of indices to an analysis of agricultural holdings economy in the LFA regions", Acta Universitatis Agriculturae et Silviculturae Mendelianae Brunensis, Vol. 58, No. 3, pp. 165-174. E-ISSN 2464-8310, ISSN 1211-8516. DOI 10.11118/actaun201058030165.

[22] Novotná, M. and Volek, T. (2015) "Efficiency of Production Factors and Financial Performance of Agricultural Enterprises", AGRIS on-line Papers in Economics and Informatics, Vol. 7, No. 4, pp. 91 - 99. ISSN 1804-1930.

[23] Rajan, R. G. and Zingales, L. (1995) "What Do We Know about Capital Structure? Some Evidence from International Data", The Journal of Finance, Vol. 50, No. 1, pp. 1421-1460. E-ISSN 1540-6261. DOI 10.1111/j.1540-6261.1995.tb05184.x.

[24] Reiff, M., Surmanová, K., Balcerzak, A. P. and Pietrzak, M. B. (2016) "Multiple Criteria Analysis of European Union Agriculture", Journal of International Studies, Vol. 9, No. 3, pp. 62-74. E-ISSN 2306-3483, ISSN 2071-8330. DOI 10.14254/2071-8330.2016/9-3/5

[25] Sardana, G. D. (2008) "Measuring business performance: A conceptual framework with focus on improvement", Performance Improvement, Vol. 47, No. 7, pp. 31-40. E-ISSN 1930-8272. DOI 10.1002/pfi.20014.

[26] Schader, C., Baumgart, L, Landert, J., Muller, A., Ssebunya, B., Blockeel, J., Weisshaidinger, R., Petrasek, R., Mészáros, D., Padel, S., Gerrad, C. Smith, L. Lindenthal, T., Niggli, U. and Stolze, M. (2016) "Using the Sustainability Monitoring and Assessment Routine (SMART) for the systematic analysis of trade-offs and synergies between sustainability dimensions and themes at farm level", Sustainability, Vol. 8, No. 3, pp. 274. ISSN 2071-1050. DOI 10.3390/su8030274.

[27] Sheela, S. C. and Karthikeyan, K. (2012) "Financial Performance of Pharmaceutical Industry in India using DuPont Analysis", European Journal of Business and Management, Vol. 4, No. 14. E-ISSN 2222-2839, ISSN 2222-1905.

[28] Soliman, M. T. (2003) "Using Industry-Adjusted DuPont Analysis to Predict Future Profitability, SSRN Electronic Journal. 48 p. ISSN 1556-5068. DOI 10.2139/ssrn.456700.

[29] Soliman, M. T. (2008) "The Use of DuPont Analysis by Market Participants", The Accounting Review, Vol. 83, No. 3, pp. 823-853. E-ISSN 1558-7967, ISSN 0001-4826. DOI 10.2308/accr.2008.83.3.823.

[30] Song, H. (2005) "Capital structure determinants An empirical study of Swedish companies", CESIS Working Paper Series in Economics and Institutions of Innovation, [Online]. Available: http:/www.diva-portal.org/smash/record.jsf?pid=diva2\%3A565199\&dswid=-6302 [Accessed: 20 July 2019]. 25 p.

[31] Ssebunya, B. R. Schader, Ch., Baumgart, L., Landert, J., Altenbuchner, Ch., Schmid, E. and Stolze, Matthias (2019) "Sustainability Performance of Certified and Non-certified Smallholder Coffee Farms in Uganda", Ecological Economics. Vol. 156, pp. 35-47. ISSN 0921-8009. DOI 10.1016/j.ecolecon.2018.09.004. 
[32] Střeleček, F. and Zdeněk, R. (2018) "Importance of objective and formal adequacy for the indicators of enterprise financial health", Agricultural Economics - Czech, Vol. 50, pp. 543-551. DOI 10.17221/5246-agricecon.

[33] Uyar, A. and Guzelyurt, M. K. (2015) "Impact of firm characteristics on capital structure choice of Turkish SMEs", Managerial Finance, Vol. 41, No. 3, pp. 286-300. ISSN 0307-4358. DOI 10.1108/MF-01-2014-0016.

[34] Vastola, A., Zdruli, P., D’Amico, M., Pasppalardo, G., Viccaro, M., DiNapoli F., Cozzi, M. and Romano, S. (2017) "A comparative multidimensional evaluation of conservation agriculture systems: A case study from a Mediterranean area of Southern Italy", Land Use Policy. Vol. 68, pp. 326-333. ISSN 0264-8377. DOI 10.1016/j.landusepol.2017.07.034.

[35] Vítková, E. and Semenova, T. (2015) "The Impact of Key Parameters Change on Economic Development of the Company", Procedia Computer Science, Vol. 6, pp. 744-749. ISSN 1877-0509. DOI 10.1016/j.procs.2015.08.605.

[36] Wagner, J. (2011) "Měření výkonnosti - vývojové tendence 2. poloviny 20. století" (Performance Measurement - Developing Tendencies of the Second Half of the $20^{\text {th }}$ Century) (In Czech), Politická ekonomie, Vol. 2011, No. 6, pp. 775-793. E-ISSN 2336-8225, ISSN 0032-3233. DOI $10.18267 /$ j.polek.821.

[37] Weill, L. (2004) "What determines leverage in transition countries?", Czech Journal of Economics and Finance (Finance a uver), Vol. 54, No. 5-6, pages 234-242. ISSN 0015-1920. 